\title{
Interannual Variation in Root Production in Grasslands Affected by Artificially Modified Amount of Rainfall
}

\author{
Karel Fiala, ${ }^{1}$ Ivan Tůma, ${ }^{1,2}$ and Petr Holub ${ }^{3}$ \\ ${ }^{1}$ Department of Vegetation Ecology, Institute of Botany, Academy of Sciences of the Czech Republic, \\ Lidická 25, 60200 Brno, Czech Republic \\ ${ }^{2}$ Department of Agrochemistry, Soil Science, Microbiology and Plant Nutrition, Faculty of Agronomy, Mendel University in Brno, \\ Zemédělská 1, 61300 Brno, Czech Republic \\ ${ }^{3}$ Global Change Research Centre, Academy of Sciences of the Czech Republic, Bèlidla 4a, 60300 Brno, Czech Republic
}

Correspondence should be addressed to Karel Fiala, karel.fiala@ibot.cas.cz

Received 6 October 2011; Accepted 8 December 2011

Academic Editors: D. Alard and C. Calfapietra

Copyright (c) 2012 Karel Fiala et al. This is an open access article distributed under the Creative Commons Attribution License, which permits unrestricted use, distribution, and reproduction in any medium, provided the original work is properly cited.

\begin{abstract}
The effect of different amounts of rainfall on the below-ground plant biomass was studied in three grassland ecosystems. Responses of the lowland (dry Festuca grassland), highland (wet Cirsium grassland), and mountain (Nardus grassland) grasslands were studied during five years (2006-2010). A field experiment based on rainout shelters and gravity irrigation simulated three climate scenarios: rainfall reduced by $50 \%$ (dry), rainfall increased by $50 \%$ (wet), and the natural rainfall of the current growing season (ambient). The interannual variation in root increment and total below-ground biomass reflected the experimentally manipulated amount of precipitation and also the amount of current rainfall of individual years. The effect of year on these below-ground parameters was found significant in all studied grasslands. In comparison with dry Festuca grassland, better adapted to drought, submontane wet Cirsium grassland was more sensitive to the different water inputs forming rather lower amount of below-ground plant matter at reduced precipitation.
\end{abstract}

\section{Introduction}

Predicted scenarios of global change include an increase of drought during the growing season and higher frequencies of extreme rainfall events [1]. Their effects on root production of various grasslands are mostly unknown. Changes in the amounts and timing of rainfall events will probably affect ecosystem processes, including those that control carbon (C) cycling and storage. If temperature and rainfall conditions would change more rapidly than the change of $\mathrm{CO}_{2}$ concentration in the atmosphere, their consequences could be much more serious [2]. These climate changes may affect the supply of $\mathrm{C}$ and energy to the soil microbial populations and subsequently alter decomposition and mineralization processes. Seasonal variation in precipitation and temperature are important controls of soil and plant processes in grasslands. Such changes may affect numerous soil, plant, and ecosystem properties in grasslands and ultimately influence their productivity and biological diversity [3-5].
Root mass and rhizosphere represent the main pool of organic matter and geobioelements of grassland ecosystems [68 ]. As these ecosystems store up to $30 \%$ of the world belowground $\mathrm{C}$, it is important to understand how variability in climate factors affects soil $\mathrm{C}$ pools/fluxes, and how $\mathrm{C} \mathrm{cy-}$ cling might be affected by changes in precipitation, due to climate change [9]. The relationships between rainfall and aboveground biomass production of grasslands have been studied quite frequently (e.g., [10-13]). The effect of water stress on grass growth and dry matter production mostly prevailed over other stress factors. The biomass of meadows mostly decreased with decreasing rainfall, reflecting so mainly the impairment of plant nutrition [14].

Production of new roots was often observed during periods of favourable soil water conditions and dry periods coincided with a decline of root dry mass (e.g., [15-20]). To the contrary, Bakker et al. [21] assessed that total fine root biomass and total fine root length were significantly higher at the dry site than at the humid site, in accordance with studies 
by Ibrahim et al. [22], Qaderi et al. [23], and Wedderburn et al. [24]. Some of them also mentioned that the significant decline in living roots and increase in dead roots corresponded with drought. Thus the total dry mass of below-ground plant parts comprises also dead undecomposed plant matter. Amounts of decomposed dead plant parts are associated, beside others, with differences in soil moisture of various ecosystems (e.g., [25-30]). Lower precipitation rate or soil moisture can mostly reduce plant matter decomposition.

Summary of the published results indicates that contradictory data on root growth and below-ground biomass in dry conditions were often presented. Although there are data on the interaction between changes in rainfall record ed over several years and the above-ground biomass production, a gap in knowledge still exists on the interannual variation in root growth and below-ground plant biomass accumulation in various grasslands at different water availabilities. Therefore, our main objective was to determine the effects of changes in rainfall amounts on the biomass production of roots. This was studied in three different grassland ecosystems occurring in lowland, highland, and mountain regions. Although rainout shelters were used by several authors [4, 31-33], the effects of different amounts of precipitation on interannual variation of root growth were not studied by them. We expected that combination of the data from an altitude gradient and from a moisture gradient will show how rainfall controls the root production and the biomass accumulation. For this goal we used data from five-year field experiments which combined naturally varying and artificially manipulated precipitation. Main and a new contribution of our study to the problem was that we obtained data with the help of two different and simultaneously used methods and results were gathered during a relatively long period of five years.

As smaller amounts of precipitation cause reductions in above-ground production, we expected to find lower root increments and lower biomass allocation to below-ground plant parts in drier years and in reduced rainfall treatments. We hypothesized that

(1) experimentally manipulated amounts of rainfall control root growth in grasslands such that the lowest yearly root increments take place in the drier treatments,

(2) the lowest accumulation of total below-ground plant parts occurs in reduced amounts of rainfall,

(3) interannual variation in root production and accumulation are characterized by their lower values recorded in dry years.

\section{Material and Methods}

2.1. Study Sites. This study was conducted during five years (2006-2010) at three sites in different grassland ecosystems. They were situated in (1) a lowland site (the Podyjí National Park near the town of Znojmo, etchplain in the southern Moravian lowland-lowland grassland), (2) a highland (the Moravian-Bohemian Highland near the village of Kamen-
TABLE 1: Soil features of grass stands of studied sites (soil layer 0$10 \mathrm{~cm}$ ).

\begin{tabular}{lccc}
\hline Features & $\begin{array}{c}\text { Lowland } \\
\text { site }\end{array}$ & $\begin{array}{c}\text { Highland } \\
\text { site }\end{array}$ & $\begin{array}{c}\text { Mountain } \\
\text { site }\end{array}$ \\
\hline $\mathrm{pH}-\mathrm{H}_{2} \mathrm{O}$ & 5.4 & 5.1 & 4.7 \\
$\mathrm{pH}-\mathrm{KCl}$ & 4.6 & 4.3 & 3.8 \\
Organic matter $(\%)$ & 9.0 & 13.9 & 8.6 \\
$\mathrm{P}\left(\mathrm{mg} \mathrm{kg}^{-1}\right)$ & 44.7 & 23.0 & 4.0 \\
$\mathrm{~K}\left(\mathrm{mg} \mathrm{kg}^{-1}\right)$ & 359 & 167 & 140 \\
$\mathrm{Mg}\left(\mathrm{mg} \mathrm{kg}^{-1}\right)$ & 166 & 163 & 57 \\
$\mathrm{Ca}\left(\mathrm{mg} \mathrm{kg}^{-1}\right)$ & 1249 & 1589 & 426 \\
$\mathrm{~N}$ tot $(\%)$ & 0.34 & 0.44 & 0.39 \\
\hline
\end{tabular}

ičky, SE of the town of Hlinsko-highland grassland), and (3) a mountain region (near the locality Bílý Kř́ž in the Moravian-Silesian Beskydy Mts.-mountain grassland). The mean annual temperature and precipitation (for the period 1961-1990) in these regions ranged from $8.5^{\circ} \mathrm{C}$ and $471 \mathrm{~mm}$ (Znojmo, Kuchařovice), through $7^{\circ} \mathrm{C}$ and $762 \mathrm{~mm}$ (Kameničky, Svratouch), to $6.5^{\circ} \mathrm{C}$ and $947 \mathrm{~mm}$ (Bílý Kř́íž). A nutrient-poor shallow soil of the Ranker type occurred in the lowland site (the bedrock is formed by granite), a brown acid gleyed soil on crystalline rocks in the highland site, and a spodo-dystric cambisol (podzol brown soil) on Flysch Godulian sandstone in the mountain site (Table 1). The lowland grassland was located near the village of Havraníky (altitude $320 \mathrm{~m}$ ). It was covered with dry acidophilous short grass vegetation dominated by the graminoids Festuca ovina, Avenella flexuosa, Anthoxantum odoratum, Arrhenatherum elatius and dicots Pimpinella saxifraga, Potentilla arenaria, Trifolium arvense, Achillea millefolium, and others. The highland grassland was characterized as a species rich stand of wet Cirsium meadow (altitude $530 \mathrm{~m}$ ). The species composition of the stand was characterized by frequent species such as Cirsium palustre, Deschampsia ceaspitosa, Agrostis capilaris, A. canina, Anthoxanthum odoratum, Polygonum bistorta, Sanguisorba officinalis, and others. A mountain Nardus grassland occurred on the third site in the Beskydy Mts. (altitude $890 \mathrm{~m}$ ). Its main components are Nardus stricta, Avenella flexuosa, Festuca rubra, and Agrostis capillaris. The monocots Holcus mollis and Carex pilulifera and dicots Veronica officinalis and Hieracium laevigatum are also frequently present. All stands were not cut in the course of the experiment.

The amount of rainfall (ambient treatment) recorded during the growing seasons at the studied sites fluctuated between 339 (recorded in 2007) and $606 \mathrm{~mm}$ (in 2010) in the lowland site and between 426 (in 2008) and $794 \mathrm{~mm}$ (in 2010) in highland site (Table 2). At the mountain site, the precipitation showed less variation over the years (532$601 \mathrm{~mm}$ ), but a considerable fluctuation within years. This was caused mostly by storm rainfalls $(810 \mathrm{~mm}$ recorded in 2007). A comparison of the deviations of the amount of actual precipitation from the long-term average values (1961-1990) recorded at nearby meteorological stations and calculated for quarters of the individual years (2006 to 2010) indicates that the stands received a lower amount 
TABLE 2: Amount of precipitation (the full natural rainfall: ambient treatment in $\mathrm{mm}$ per growing season) recorded at the studied sites (Lowland: Havraníky, Highland: Kameničky; Mountain: Bílý Křŕž) in the growing seasons 2006 to 2010.

\begin{tabular}{cccc}
\hline Year & $\begin{array}{c}\text { Lowland } \\
\text { grassland }\end{array}$ & $\begin{array}{c}\text { Highland } \\
\text { grassland }\end{array}$ & $\begin{array}{c}\text { Mountain } \\
\text { grassland }\end{array}$ \\
\hline 2006 & 446 & 687 & 574 \\
2007 & 339 & 513 & 810 \\
2008 & 361 & 426 & 601 \\
2009 & 511 & 606 & 532 \\
2010 & 606 & 794 & 580 \\
\hline
\end{tabular}

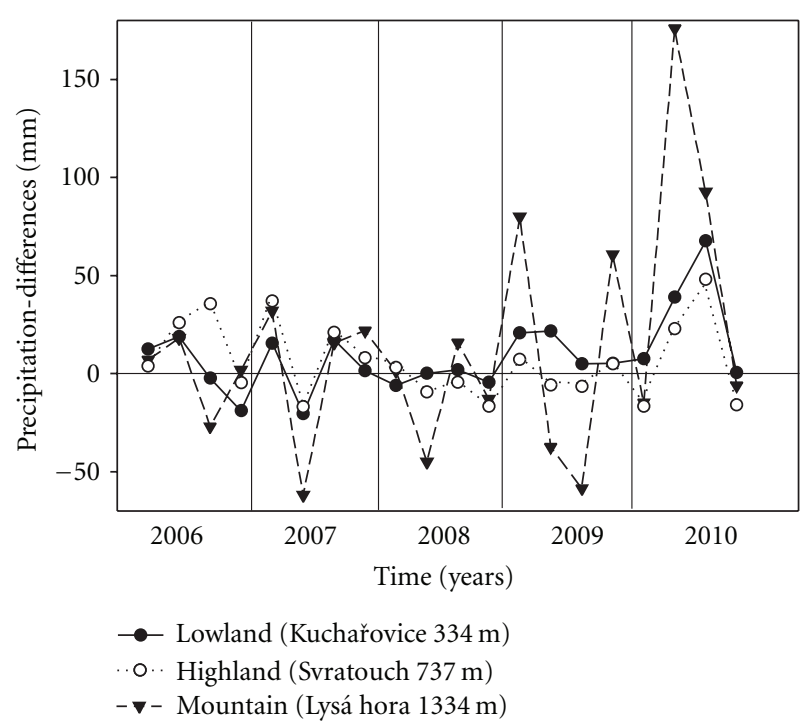

FIGURE 1: Differences in the amount of precipitation from the longterm average values (1961-1990) recorded at the meteorological stations Kuchařovice (lowland), Svratouch (highland), and Lysá hora (mountain, approximately 9,4 , and $8 \mathrm{~km}$ from studied sites, resp.) and calculated for quarters of the years of 2006 to 2010.

of precipitation at the beginning of the growing seasons 2007 and 2008 (second quarters, Figure 1). The data on the amount of precipitation measured at the studied sites and comparison with data from meteorological stations indicate that the 2007 and 2008 growing seasons were drier particularly in comparison with 2006 and 2010 (Figure 1). In the highland grassland, soil moisture conditions given by amount of precipitation occurring from the end of May to June were also influenced here by a higher underground water table, ranging about $-20 \mathrm{~cm}$ below soil surface due to the melting of a huge amount of snow. However, in summer months, underground water table decreased here often down to $-50 \mathrm{~cm}$.

2.2. Experimental Design. Twelve $2 \times 3 \mathrm{~m}$ plots were laid out in an area of relatively homogeneous grasslands at each of the three localities (four replications of each treatment were in block design). Rainout shelters constructed above the canopy of grass stands and a gravity irrigation system simulated three scenarios: (1) rainfall reduced by $50 \%$ (dry treatment), (2) rainfall enhanced by $50 \%$ (wet treatment), and (3) the full natural rainfall of the current growing season (ambient treatment-amb). For the dry treatment, rainout shelters constructed over the experimental plots consisted of a steel frame supporting plastic transparent strips (small troughs, see [34]) that covered $50 \%$ of the experimental plots. Such rain water shelters with a roof consisting of bands of transparent blocks represent well-replicated experiments with minimal secondary microenvironmental effects [34]. The water was piped as gravity irrigation into the corresponding wet treatment plots. A $0.2 \mathrm{~m}$ wide trench was dug and sheathed with a plastic foil to separate the soil of the roofed and irrigated areas from the neighbouring soil. No measurements were performed in a $0.25 \mathrm{~m}$ wide peripheral.

2.3. Below-Ground Plant Parts Analyses. In order to assess yearly root increments (root production), the in-growth core technique was used during five years. Eight plastic-mesh tubes with river sand were inserted into holes $(5 \mathrm{~cm}$ in diameter, $15 \mathrm{~cm}$ depth) in experimental treatments (two in each replicated plot) at the beginning of the growing season. The tubes were lifted at the end of the growing season and roots were washed, dried, and weighed. The total below-ground biomass (TBB) was collected at the end of five growing seasons. Eight soil cores were taken to the depth of $15 \mathrm{~cm}$ in experimental plots with a root auger (diameter $9.4 \mathrm{~cm}$ ) representing more than $90 \%$ of total below-ground dry mass of studied plant communities. The below-ground plant parts were washed free of soil over a $0.5 \mathrm{~mm}$ mesh sieve. Samples were separated into total roots and rhizomes with shoot bases (referred as rhizomes for simplification), dried, and weighed.

2.4. Statistical Analysis. Data were evaluated by an analysis of variance, using statistical package STATISTICA 9. A repeated measures ANOVA analysis was used to test the effect of manipulated rainfall as nonrepeated factor on both root increments and dry mass of below-ground plant parts, where the years were used as repeated measures factor. Significant differences among means were tested (Tukey HSD test $(P<$ $0.05)$ after ANOVA). Linear correlation analyses were performed between root increments, TBB, and precipitation input to determine whether these parameters are related.

\section{Results}

3.1. Yearly Root Increments and Their Interannual Variations. The repeated measures analysis has shown that the yearly root increments (YRIs) were significantly affected by rainfall input in the lowland and mountain grasslands (Table 3). In addition, correlation analysis summarizing five-year data indicated that the YRI increased with enhanced rainfall input, but significantly only in lowland and highland grasslands (Figure 2). Thus the effect of rainfall input on root increment was observed in all studied grasslands. In the highland site, the rather variable data on YRI recorded during five years may explain the mostly nonsignificant results. Although often not significant, a tendency to a higher YRI was found in wet treatments compared to the dry treatments in 
TABLE 3: The effect of rainfall input and year on the root increment, roots, rhizomes, and total below-ground biomass (TBB): results of repeated measures analysis of variance (ANOVA), using years as repeated measures factor (NS: not significant, ${ }^{*} P<0.05,{ }^{* *} P<0.01$, $* * * P<0.001 ;$ df error $=84)$.

\begin{tabular}{|c|c|c|c|c|c|c|c|c|c|}
\hline \multirow[t]{2}{*}{ Effect } & \multirow[b]{2}{*}{$\mathrm{df}$} & \multicolumn{2}{|c|}{ Root increment } & \multicolumn{2}{|c|}{ Rhizomes } & \multicolumn{2}{|c|}{ Roots } & \multicolumn{2}{|c|}{ TBB } \\
\hline & & $F$ & $P$ & $F$ & $P$ & $F$ & $P$ & $F$ & $P$ \\
\hline \multicolumn{10}{|c|}{ Lowland grassland } \\
\hline Rainfall input & 2 & 8.0 & $* *$ & 4.5 & $*$ & 2.0 & NS & 2.4 & NS \\
\hline Year & 4 & 12.4 & $* * *$ & 0.9 & NS & 1.9 & NS & 2.6 & $*$ \\
\hline Interaction & 8 & 1.5 & NS & 2.1 & $*$ & 1.8 & NS & 1.2 & NS \\
\hline \multicolumn{10}{|c|}{ Highland grassland } \\
\hline Rainfall input & 2 & 2.5 & NS & 7.8 & $* *$ & 12.9 & $* * *$ & 14.5 & $* * *$ \\
\hline Year & 4 & 8.8 & $* * *$ & 1.7 & NS & 10.8 & $* * *$ & 4.5 & $* *$ \\
\hline Interaction & 8 & 1.0 & NS & 1.6 & NS & 1.3 & NS & 0.8 & NS \\
\hline \multicolumn{10}{|c|}{ Mountain grassland } \\
\hline Rainfall input & 2 & 9.3 & $* *$ & 1.2 & NS & 2.7 & NS & 5.4 & NS \\
\hline Year & 4 & 11.0 & $* * *$ & 3.2 & $*$ & 19.7 & $* * *$ & 10.8 & $* * *$ \\
\hline Interaction & 8 & 1.6 & NS & 0.1 & NS & 0.7 & NS & 0.4 & NS \\
\hline
\end{tabular}

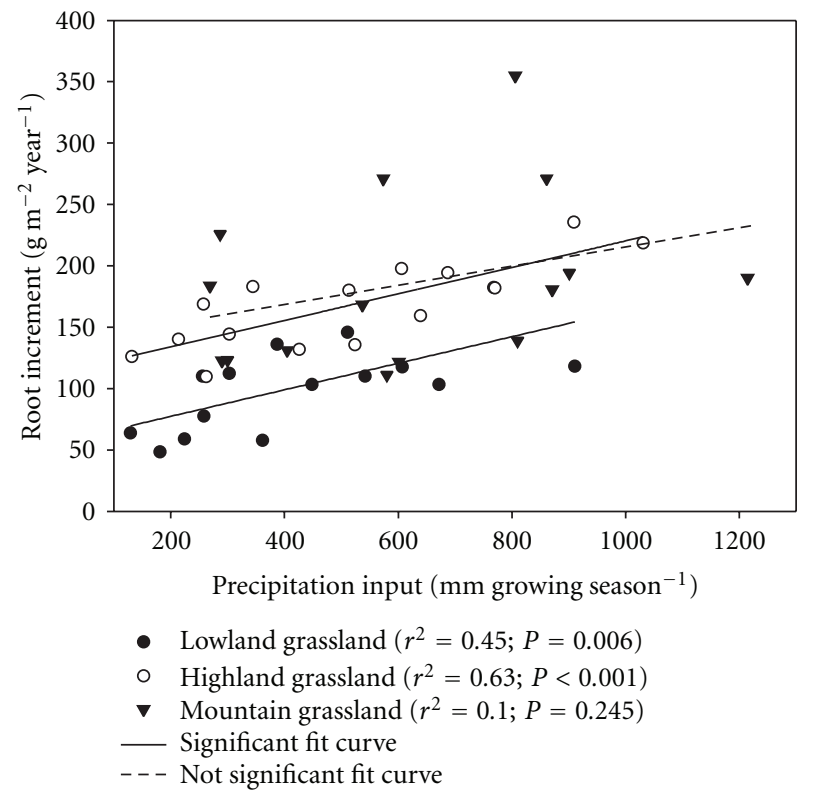

FIGURE 2: Relationship between the yearly root increment and precipitation input along the experimental precipitation gradient. Each point indicates annual mean.

all studied grassland (Table 4). The percentage increase or decrease in YRI in dry and wet treatments in comparison with the ambient precipitation recorded in five years (20062010 ) is summarized in Figure 3. According to 5-year means, marked increase in root production $(38,15$, and $54 \%$ ) has been observed in the wet treatment in the lowland, highland and mountain grassland, respectively. On the other hand, $21 \%$ reduction (in average) of root production was found in dry treatment of the lowland grassland, while no effect of decreased rainfall input was noted in the highland and mountain grasslands in comparison with ambient treatment (Figure 3).
In the first three years (2006-2008), the YRI recorded in the dry treatment of the lowland Festuca grassland represented, on the average, only about $49 \%\left(57 \mathrm{~g} \mathrm{~m}^{-2}\right.$ year $\left.^{-1}\right)$ of the root biomass formed in stands affected by higher precipitation input (wet treatment, Table 4). However, in 2009 and 2010, a significantly greater root production (mostly above $100 \mathrm{~g} \mathrm{~m}^{-2}$ year $^{-1}$ ) was formed in Festuca grassland in the dry treatment than in previous years and even reached values recorded in the wet treatments in 2010 (Table 4). In the course of five years, a decreasing tendency in YRI was found with time in all rainfall input treatments of the highland Cirsium grassland. This was documented by the highest significant values recorded in 2006 (183 and $219 \mathrm{~g} \mathrm{~m}^{-2}$ year $^{-1}$ in the dry and wet treatments, resp.) and lower amount of roots recorded in 2010 (69, resp., 63\% of the values at the beginning of experiment, Table 4). Substantial increases of YRI were found in the ambient and wet treatments only in 2009, probably due to improved water conditions after two relatively dry years. In mountain Nardus grassland, mostly significantly higher values of YRI were assessed through all treatments in the 2006 and 2009 growing seasons (Table 4). During five years, the data on YRI averaged here 156, 140, and $229 \mathrm{~g} \mathrm{~m}^{-2}$ year $^{-1}$ in the dry, ambient, and wet treatments, respectively. The significantly highest YRI value (355 $\mathrm{g} \mathrm{m}^{-2}$ year ${ }^{-1}$ ) was found in the wet treatment in 2009.

\subsection{Below-Ground Plant Parts and Their Interannual Varia-} tions. The repeated measures analysis confirmed the significant effect of a varying rainfall input on the accumulation of roots, rhizomes, and $\mathrm{TBB}$ in highland and rhizomes in lowland grasslands (Table 3). Concerning interactions, below-ground plant parts were not affected by the interaction of rainfall input and year, except rhizomes in lowland grassland. In addition, the increasing dry mass of both roots (not presented) and TBB in the stand of highland Cirsium grassland correlated positively with the increasing amount of precipitation (Figure 4). Values recorded in the other two grassland types were more variable and this relationship was 
TABLE 4: Mean values $( \pm$ SE) of yearly root increment under different amounts of precipitation (dry, ambient, and wet treatments) recorded in five years (2006-2010): results of one-way ANOVA analysis (NS: not significant, ${ }^{*} P<0.05,{ }^{* *} P<0.01$, ${ }^{* * *} P<0.001$ ). Different letters denote significantly different values for rhizomes, roots, and total separately (Tukey HSD test $(P<0.05)$ after ANOVA).

\begin{tabular}{|c|c|c|c|c|}
\hline \multirow[t]{2}{*}{ Year } & \multicolumn{4}{|c|}{ Yearly root increment } \\
\hline & Dry & Ambient & Wet & $P$ \\
\hline \multicolumn{5}{|c|}{ Lowland grassland } \\
\hline 2006 & $58.8 \pm 15 a$ & $103.1 \pm 28 b$ & $103.2 \pm 25 b$ & $* *$ \\
\hline 2007 & $63.8 \pm 16 a$ & $77.5 \pm 17 \mathrm{a}$ & $136.0 \pm 63 b$ & $*$ \\
\hline 2008 & $48.5 \pm 9 a$ & $57.6 \pm 20 \mathrm{a}$ & $110.1 \pm 26 b$ & $* * *$ \\
\hline 2009 & $110.0 \pm 19 a$ & $145.7 \pm 43 \mathrm{ab}$ & $182.4 \pm 59 b$ & NS \\
\hline 2010 & $112.4 \pm 30 \mathrm{a}$ & $117.6 \pm 39 a$ & $118.1 \pm 40 \mathrm{a}$ & NS \\
\hline \multicolumn{5}{|c|}{ Highland grassland } \\
\hline 2006 & $182.9 \pm 38 \mathrm{a}$ & $194.4 \pm 41 \mathrm{a}$ & $218.6 \pm 29 a$ & NS \\
\hline 2007 & $168.6 \pm 54 a$ & $180.1 \pm 53 a$ & $181.8 \pm 44 a$ & NS \\
\hline 2008 & $140.2 \pm 30 \mathrm{a}$ & $131.9 \pm 56 a$ & $159.4 \pm 32 \mathrm{a}$ & NS \\
\hline 2009 & $144.2 \pm 46 a$ & $197.8 \pm 50 \mathrm{ab}$ & $235.6 \pm 50 \mathrm{~b}$ & * \\
\hline 2010 & $126.0 \pm 44 a$ & $109.8 \pm 29 a$ & $135.8 \pm 49 a$ & NS \\
\hline \multicolumn{5}{|c|}{ Mountain grassland } \\
\hline 2006 & $225.8 \pm 69 a$ & $270.9 \pm 44 a$ & $271.0 \pm 73 a$ & NS \\
\hline 2007 & $131.0 \pm 28 \mathrm{a}$ & $138.9 \pm 75 a$ & $190.0 \pm 83 a$ & NS \\
\hline 2008 & $123.1 \pm 59 a$ & $121.4 \pm 41 \mathrm{a}$ & $194.4 \pm 47 b$ & $*$ \\
\hline 2009 & $183.5 \pm 100 a$ & $168.0 \pm 45 a$ & $354.8 \pm 155 b$ & $*$ \\
\hline 2010 & $122.6 \pm 34 \mathrm{a}$ & $111.0 \pm 31 \mathrm{a}$ & $180.5 \pm 23 b$ & $* *$ \\
\hline
\end{tabular}

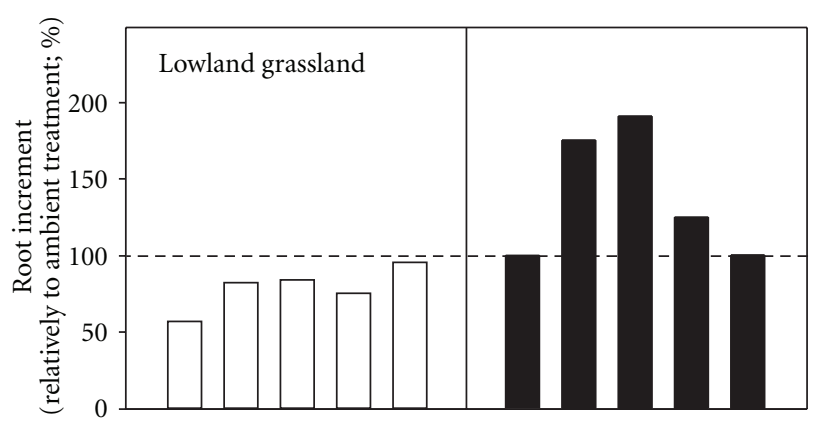

(a)

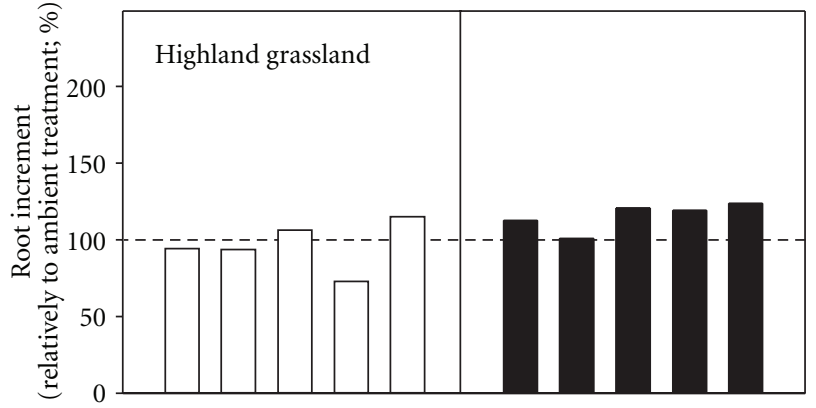

(b)

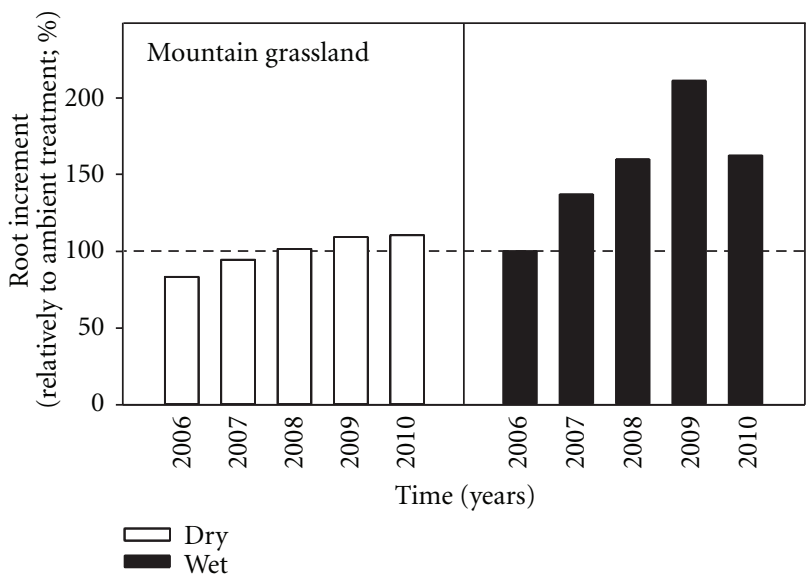

(c)

FIGURE 3: Percentage increase or decrease in yearly root increment (ambient treatment $=100 \%$ ) in dry and wet treatments recorded in five years (2006-2010). 
TABLE 5: Mean values ( \pm SE) of dry mass of rhizomes, roots, and total below-ground biomass (TBB) under different amounts of precipitation (dry, ambient and wet treatments) recorded in five years (2006-2010): results of one-way ANOVA analysis (NS: not significant, ${ }^{*} P<0.05$, $\left.{ }^{* *} P<0.01,{ }^{* * *} P<0.001\right)$. Different letters denote significantly different values for rhizomes, roots and total separately (Tukey HSD test $(P<0.05)$ after ANOVA $)$.

\begin{tabular}{|c|c|c|c|c|c|c|c|c|c|c|c|}
\hline \multirow[t]{2}{*}{ Year } & \multicolumn{2}{|c|}{ Rhizomes } & \multirow[b]{2}{*}{$P$} & \multicolumn{3}{|c|}{ Roots } & \multirow[b]{2}{*}{$P$} & \multicolumn{4}{|c|}{ TBB } \\
\hline & $\mathrm{Amb}$ & Wet & & Dry & Amb & Wet & & Dry & $\mathrm{Amb}$ & Wet & $P$ \\
\hline \multicolumn{12}{|c|}{ Lowland grassland } \\
\hline $2006225 \pm 33 a$ & $219 \pm 26 a$ & $169 \pm 26 a$ & NS & $830 \pm 34 a$ & $732 \pm 52 \mathrm{a}$ & $854 \pm 81 \mathrm{a}$ & NS & $1056 \pm 56 a$ & $951 \pm 56 a$ & $1022 \pm 99 a$ & NS \\
\hline $2007165 \pm 31 \mathrm{a}$ & $163 \pm 23 a$ & $186 \pm 35 a$ & NS & $654 \pm 39 a$ & $881 \pm 75 b$ & $919 \pm 53 b$ & $* *$ & $818 \pm 47 a$ & $1045 \pm 86 b$ & $1104 \pm 72 b$ & $*$ \\
\hline $2008142 \pm 25 a$ & $192 \pm 44 \mathrm{a}$ & $349 \pm 62 b$ & $*$ & $829 \pm 54 a$ & $917 \pm 112 \mathrm{a}$ & $764 \pm 41 \mathrm{a}$ & NS & $971 \pm 40 \mathrm{a}$ & $1109 \pm 118 \mathrm{a}$ & $1076 \pm 72 \mathrm{a}$ & NS \\
\hline $2009192 \pm 26 a$ & $131 \pm 29 a$ & $180 \pm 41 \mathrm{a}$ & NS & $725 \pm 71 a$ & $813 \pm 68 a$ & $679 \pm 67 a$ & NS & $917 \pm 74 a$ & $943 \pm 71 a$ & $859 \pm 94 a$ & NS \\
\hline $2010109 \pm 20 \mathrm{a}$ & $166 \pm 25 \mathrm{a}$ & $321 \pm 122 \mathrm{a}$ & NS & $729 \pm 115 a$ & $1043 \pm 103 a$ & $953 \pm 154 \mathrm{a}$ & NS & $928 \pm 109 a$ & $1208 \pm 118 \mathrm{a}$ & $1294 \pm 205 a$ & NS \\
\hline \multicolumn{12}{|c|}{ Highland grassland } \\
\hline $2006367 \pm 57 a$ & $464 \pm 107 a$ & $565 \pm 82 a$ & NS & $1549 \pm 96 a$ & $1609 \pm 72 \mathrm{ab}$ & $1854 \pm 94 b$ & $*$ & $1916 \pm 124 a$ & $2074 \pm 171 \mathrm{ab}$ & $2419 \pm 142 b$ & $*$ \\
\hline $2007236 \pm 44 a$ & $347 \pm 48 \mathrm{ab}$ & $419 \pm 72 b$ & $*$ & $961 \pm 99 a$ & $1282 \pm 117 b$ & $1360 \pm 100 b$ & $*$ & $1197 \pm 124 \mathrm{a}$ & $1629 \pm 149 b$ & $1779 \pm 135 b$ & $*$ \\
\hline $2008300 \pm 26 a$ & $421 \pm 98 \mathrm{a}$ & $989 \pm 310 b$ & $*$ & $1009 \pm 124 a$ & $1403 \pm 56 b$ & $1368 \pm 104 b$ & $*$ & $1309 \pm 121 \mathrm{a}$ & $1824 \pm 125 b$ & $2357 \pm 294 b$ & $* *$ \\
\hline $2009276 \pm 55 a$ & $754 \pm 159 b$ & $680 \pm 166 b$ & * & $1146 \pm 131 a$ & $1179 \pm 86 a$ & $1313 \pm 129 a$ & NS & $1422 \pm 180 a$ & $1932 \pm 158 \mathrm{ab}$ & $1993 \pm 205 b$ & $*$ \\
\hline $2010503 \pm 148 \mathrm{a}$ & $449 \pm 138 \mathrm{a}$ & $568 \pm 108 \mathrm{a}$ & NS & $1185 \pm 104 a$ & $1198 \pm 90 \mathrm{a}$ & $1651 \pm 118 b$ & $* *$ & $1641 \pm 215 \mathrm{a}$ & $1647 \pm 194 \mathrm{a}$ & $2112 \pm 218 \mathrm{a}$ & NS \\
\hline \multicolumn{12}{|c|}{ Mountain grassland } \\
\hline $2006401 \pm 102 \mathrm{a}$ & $499 \pm 82 \mathrm{a}$ & $486 \pm 76 a$ & NS & $1365 \pm 116 \mathrm{a}$ & $1519 \pm 111 \mathrm{a}$ & $1568 \pm 211 \mathrm{a}$ & NS & $1766 \pm 151 \mathrm{a}$ & $2018 \pm 94 \mathrm{a}$ & $2054 \pm 184 \mathrm{a}$ & NS \\
\hline $2007422 \pm 114 a$ & $526 \pm 76 a$ & $511 \pm 92 a$ & NS & $982 \pm 75 a$ & $954 \pm 70 \mathrm{a}$ & $1015 \pm 125 a$ & NS & $1404 \pm 103 a$ & $1479 \pm 112 \mathrm{a}$ & $1526 \pm 113 a$ & NS \\
\hline $2008317 \pm 97 a$ & $434 \pm 78 a$ & $457 \pm 68 a$ & NS & $855 \pm 82 a$ & $947 \pm 61 \mathrm{ab}$ & $1114 \pm 56 b$ & $*$ & $1172 \pm 96 a$ & $1380 \pm 134 a b$ & $1571 \pm 111 b$ & $*$ \\
\hline $2009330 \pm 77 a$ & $381 \pm 92 \mathrm{a}$ & $383 \pm 94 a$ & NS & $888 \pm 52 a$ & $1167 \pm 49 b$ & $1154 \pm 76 b$ & $* *$ & $1218 \pm 105 a$ & $1548 \pm 121 \mathrm{a}$ & $1536 \pm 157 a$ & NS \\
\hline $2010227 \pm 48 a$ & $356 \pm 61 \mathrm{a}$ & $322 \pm 55 a$ & NS & $1372 \pm 91 \mathrm{a}$ & $1318 \pm 90 \mathrm{a}$ & $1429 \pm 53 a$ & NS & $1599 \pm 130 \mathrm{a}$ & $1674 \pm 141 \mathrm{a}$ & $1751 \pm 48 \mathrm{a}$ & NS \\
\hline
\end{tabular}

not significant (Figure 4). The greatest differences in belowground plant parts were usually recorded between dry and wet treatments. In lowland grassland, TBB fluctuated in a narrow range of values and differences between plant parts and years were mostly not significant. Nevertheless, these changes have shown here significant differences between dry and wet treatments recorded in the second year of experiment (Table 5). Similar significant decreases were also found in mountain grassland, but only for roots (2008 and 2009) and TBB (2008). In the highland grassland, however, significant differences in below-ground plant parts between dry and wet treatments were found nearly in all years (Table 5).

During five years studied, the TBB fluctuated between 1197 and $1916 \mathrm{~g} \mathrm{~m}^{-2}$ in dry and 1779 and $2419 \mathrm{~g} \mathrm{~m}^{-2}$ in wet treatments of the highland grassland. In addition, the TBB ranged between 818 and $1056 \mathrm{~g} \mathrm{~m}^{-2}$ in dry and 859 to $1294 \mathrm{~g} \mathrm{~m}^{-2}$ in wet treatments in the lowland grassland and between 1172 and $1766 \mathrm{~g} \mathrm{~m}^{-2}$ in dry and 1526 to 2054 in wet mountain grassland (Table 5 ). Thus TBB of those grasslands was generally lower in comparison with values of Cirsium highland grassland. According to 5-year means, both the greatest reduction (by 15 and 18\%, resp.) and accumulation (10 and 17\%, resp.) of the root biomass and TBB have been noted in the highland grassland (Figure 5). On the other hand, the mountain grassland was characterized by relatively stable variations in the amount of below-ground plant parts under different amounts of rainfall (Figure 5). In addition, the decrease in the amount of rainfall input resulted also in a lower amount of rhizomes in dry treatment than that in

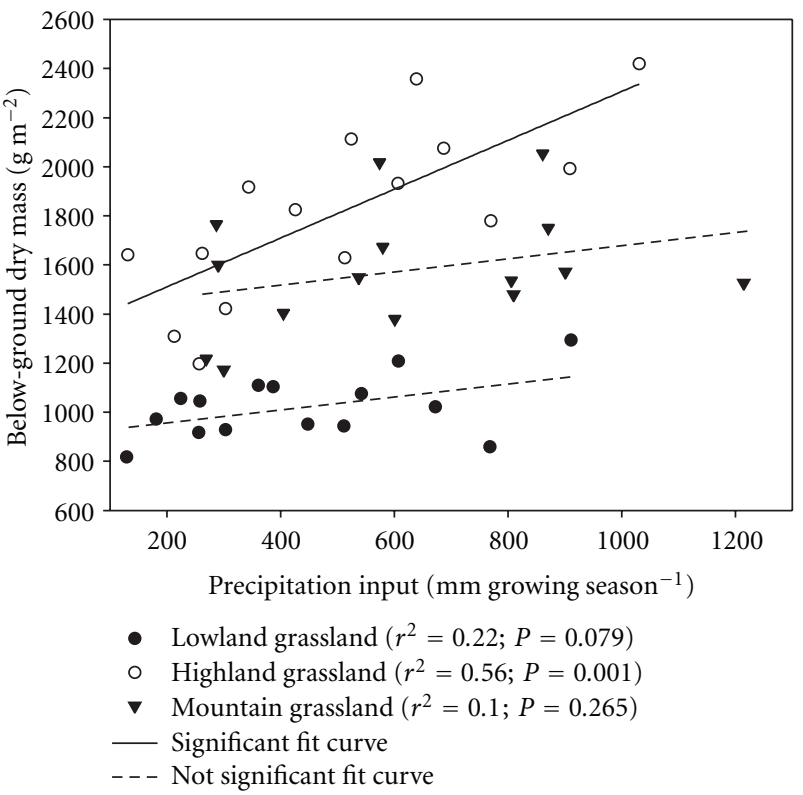

FIGURE 4: Relationship between the amount of total below-ground plant dry mass and precipitation input along the experimental precipitation gradient. Each point indicates annual mean.

wet treatments in highland (significant in 2007-2009) and lowland grasslands (significant in 2008) (Table 5).

Interannual changes in below-ground biomass of lowland Festuca grassland were characterized by fluctuation of data in a narrow range of values and differences between 


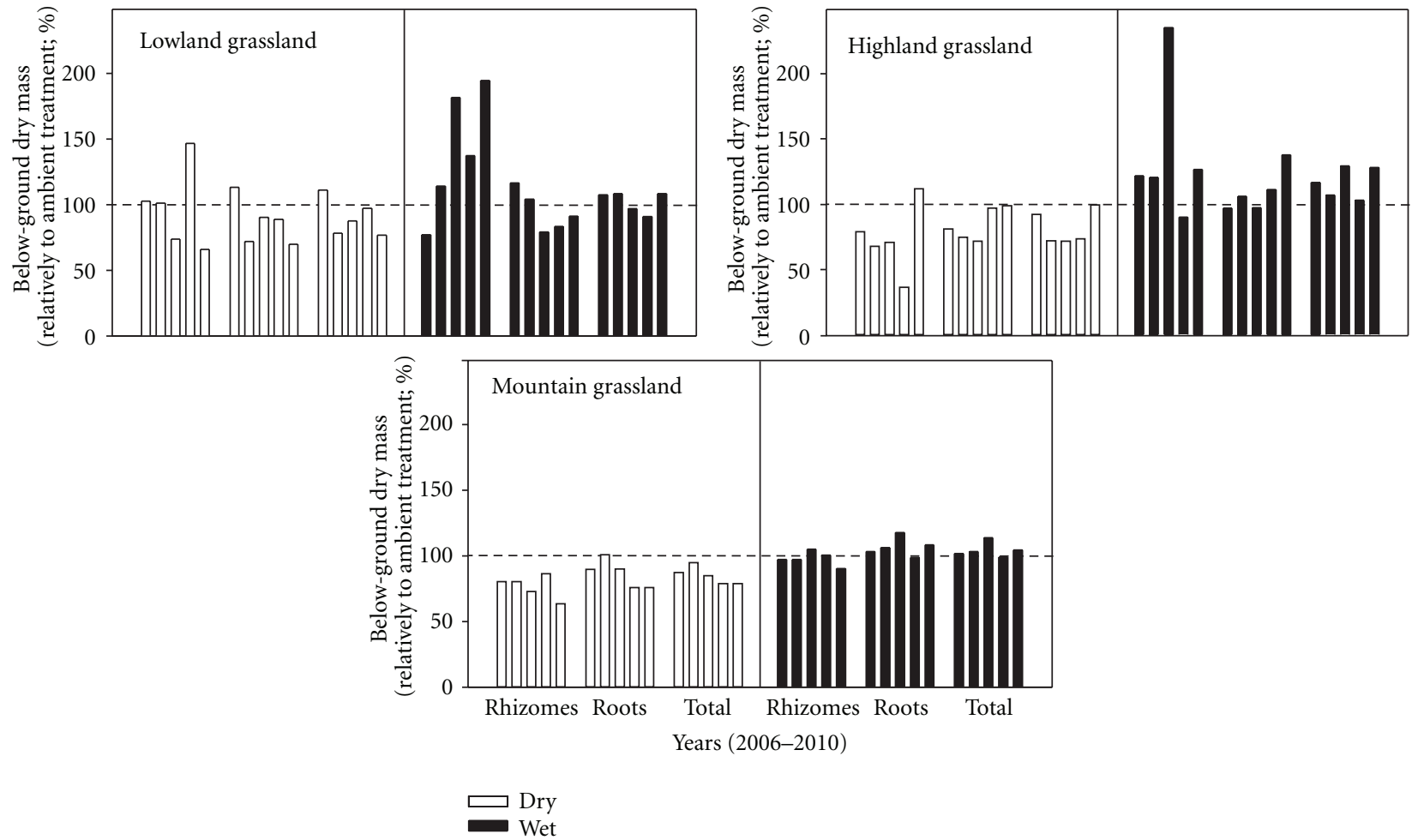

FIgURE 5: Percentage increase or decrease in dry mass of rhizomes, roots, and total below-ground plant biomass (ambient treatment $=100 \%)$ in dry and wet treatments recorded in five years (2006-2010).

them were mostly not significant (Table 5). Nevertheless, several significant differences in roots and TBB between dry and wet treatments were found in the second year (2007). In highland and mountain grasslands, respectively, a considerable significant reduction of roots (by 327 and $565 \mathrm{~g} \mathrm{~m}^{-2}$ ) and TBB (by 445 and $539 \mathrm{~g} \mathrm{~m}^{-2}$ ) occurred in ambient treatments in the second year (2007) in comparison with the previous year. A decreasing tendency in the dry mass of these plant parts also occurred in the following two years, particularly in the dry treatment of the mountain grassland (Table 5). The greatest significant differences between rainfall input treat-ments were here found in the third year when 1571 and only $1172 \mathrm{~g} \mathrm{~m}^{-2}$ of TBB accumulated in wet and dry treatments, respectively. On the contrary, an increase in root and TBB mostly occurred in all treatments in the studied grasslands in the last year (2010). In all grasslands studied, the mean values of dry mass of rhizomes including shoot bases were also lower in the dry in comparison with wet treatments, but mostly not significantly (Table 5 ). In the highland grassland, however, the pronounced reduction of rhizomes recorded due to lower precipitation was mostly significant.

\section{Discussion}

4.1. Yearly Root Increments and Their Interannual Variations. Our assumption that root growth is affected by experimentally manipulated rainfall inputs was confirmed for all studied grasslands. However, this fact was documented by significant effects of rainfall input treatments in ANOVA analyses in lowland and mountain grasslands and by correlation analyses which demonstrated that the yearly root increment (YRI) increased linearly with increasing precipitation in lowland and highland grasslands.

Our results are supported by findings of several authors. For example, the lowest yearly production of new roots and root elongation rates were found due to a decrease of the soil water content (e.g., $[17,35,36])$. Based on a large collection of field measures, Hui and Jackson [8] concluded that the proportion of the below-ground net biomass production in the total net primary production was negatively correlated with the average annual temperature and precipitation across sites. Our results indicate higher root increments in cool and wet highland and mountain sites, while lower values in dry and warmer environments of lowland sites were found. Perez and Frangi [37] reported that below-ground net productivity in grassland sites increased with altitude. On the other hand, a greater root production at lower than at higher elevated sites was found in several temperate grasslands [38]. Nevertheless, root production may not be a simple function of altitude [38,39]. In our case, both altitude and amount of rainfall can explain obtained results of individual sites.

The repeated measures analysis also exhibited the effect of year on YRI in all studied grasslands. The results show the lowest YRI in the dry treatment of the lowland dry grassland and a decreased root production in the dry treatments of the highland and mountain grasslands, particularly during the first three years. This fact can be associated with the lower regular rainfall recorded during this period. The YRI significantly increased in the Festuca lowland grassland in 2009 and 2010. In these years, the amount of precipitation was 
above the long-term averages. In the mountain grassland, the YRI varied over a wide range of values. This could also be associated with fluctuating amounts of the current precipitation. Production of new roots was observed during periods of favourable soil water conditions $[40,41]$ and the decline in the below-ground net biomass production was found in dry years $[15,16,18]$. In addition, the below-ground net primary production was not related to the early but to the late rainfall in the rainy season [17]. However, Fitter et al. [39] concluded that a yearly increase in root biomass can be rather a function of changes in length of the growing season, not soil temperature. In the present study, in the drier vegetation seasons (2007 and 2008) decreased YRIs were recorded in nearly all grasslands and treatments, but particularly in the mountain grassland. Thus these interannual variations in root production reflected not only the experimentally manipulated amount of precipitation but also the current rainfall, that is, dry and wet conditions of individual growing seasons.

4.2. Below-Ground Plant Parts and Their Interannual Variations. We expected to find a lower accumulation of belowground plant parts in dry conditions. The repeated measures analysis showed that data of dry mass of all belowground plant parts of the studied wet Cirsium grassland in highland were only significantly affected by the rainfall input treatment. In this grassland, the introduced reduction and increase of amounts of rain were connected with a decrease or increase in all below-ground plant parts. Correlation analysis suggested a significant positive relationship between precipitation input and root and TBB in the highland grassland. These our results support the hypothesis that the different amounts of rainfall will be reflected in the below-ground plant biomass and the lowest accumulation of total belowground plant parts will occur in reduced amounts of rainfall.

Dry conditions appear to influence the root mortality (e.g., [24, 40-42]). Above all summer droughts can lead to increased root mortality, thereby reducing root biomass. Hayes and Seastedt [15] also mention that the significant decline in living roots and increase in dead roots corresponded with drought. Therefore the disappearance of roots and consequently decrease in root dry mass could have resulted from the low rainfall. Decomposition processes can modify the amount of TBB in different soil moisture conditions, resulting in varying accumulation of below-ground undecomposed plant litter. Drought mostly resulted in a decline of below-ground dry mass [43].

The repeated measures analysis also showed that TBB of all studied grasslands changed significantly with year. Thus both experimentally and naturally altered rainfall inputs were associated with variation in values of the belowground dry mass, although not significantly in all five years. Not significant data on interactions between rainfall input and year indicated that dry or wet years reduced or increased below-ground biomass in dry and wet treatments in the same extent. The interannual variation was characterized by a decreasing tendency in the amount of TBB after experimental reduction of precipitation in all studied grasslands. In addition, a considerable reduction of the TBB occurred through all rainfall input treatments in the studied highland and mountain grasslands in the second year of the experiment (2007). In comparison with other years, the grasslands received the lowest amount of precipitation in the first part of this growing season. In wet Cirsium highland grassland, differences in water availability were reflected, mostly significantly, in accumulated root dry matter. Therefore, our last assumption to find a lower root accumulation in dry years was confirmed in wet Cirsium grassland.

The results of the present study correspond with data of other authors (e.g., $[15,18,44,45]$ ) who noted that root biomass and root length were lower in dry years. Drought and soil moisture decrease reduced decomposition processes of dead plant matter, whereas enhanced soil moisture can accelerate decomposition below-ground in many ecosystems (e.g., $[26,27,29,30,46])$. Changes in the distribution of the rain during the year may be more important than changes in the total amount of rain. Mid-growing season drought can result in accelerated death and decomposition of new roots [15]. Below-ground turnover rates in grasslands decreased with altitude [37]. This fact was confirmed by data on total root dry mass from different regions summarized by Fiala $[47,48]$. Therefore the total dry mass of below-ground plant parts comprises also various amounts of dead undecomposed plant matter, in upper elevation sites particularly. Nevertheless, recorded increase of root biomass in studied years can indicate rather new root growth than the decreased decomposition.

\section{Conclusions}

Our results indicate the strong effect of reduced precipitation on decrease of roots and TBB in the wet submontane Cirsium grassland, occurring often in the central European region. Below-ground plant matter is considered as stabilizing element of grasslands, which also functioning as water storage in the landscape. Therefore a substantial reduction of root matter can contribute to destabilization of grassland ecosystems. In addition, the wet submontane Cirsium grassland often occurs in spring regions providing supply of drinking water. Although the YRI decreased linearly with decreasing precipitation in lowland and highland grasslands, the same relationship was not found for roots and TBB in the mountain. In the studied mountain Nardus grassland, amount of precipitations cannot be always the main predictor of the amount of below-ground plant biomass due to relatively high current rainfall. The dry Festuca grassland can be better adapted to dry conditions and below-ground biomass fluctuated here in a narrow range of values. The new information related to the influence of precipitation on growth and accumulation of roots is particularly important, because most current literature has focused on the aboveground biomass production, but grasslands accumulate larger plant biomass below-ground.

\section{Acknowledgments}

This research was supported by Grant nos. 526/06/0556 (Grant Agency of the Czech Republic) and MSM6215648905 
(Research plan MSM), by project CzechGlobe (CZ.1.05/1.1.00/02.0073), and by Research Intentions AV0Z 60050516 and AV0Z 60870520. The authors are indebted to Dr. J. P. Kaiser (The Netherland) for his review of the text.

\section{References}

[1] K. E. Trenberth, A. Dai, R. M. Rasmussen, and D. B. Parsons, "The changing character of precipitation," Bulletin of the American Meteorological Society, vol. 84, no. 9, pp. 1205-1161, 2003.

[2] D. W. Lawlor, "Plant responses to global change: temperature and drought stress," in Responses of Plant Metabolism to Air Pollution and Global Change, L .J. de Kok and I. Stulen, Eds., pp. 193-207, Backhuys Publishers, Leiden, The Netherlands, 1998.

[3] A. K. Knapp, P. A. Fay, J. M. Blair et al., "Rainfall variability, carbon cycling, and plant species diversity in a mesic grassland," Science, vol. 298, no. 5601, pp. 2202-2205, 2002.

[4] P. A. Fay, D. M. Kaufman, J. B. Nippert, J. D. Carlisle, and C. W. Harper, "Changes in grassland ecosystem function due to extreme rainfall events: implications for responses to climate change," Global Change Biology, vol. 14, no. 7, pp. 1600-1608, 2008.

[5] J. Kreyling, M. Wenigmann, C. Beierkuhnlein, and A. Jentsch, "Effects of extreme weather events on plant productivity and tissue die-back are modified by community composition," Ecosystems, vol. 11, no. 5, pp. 752-763, 2008.

[6] M. Rychnovska, "Grasslands: a multifunctional link between natural and man-made ecosystems," Ekológia (ČSSR), vol. 2, no. 4, pp. 337-345, 1983.

[7] N. L. Stanton, "The underground in grasslands," Annual Review of Ecology and Systematics, vol. 19, pp. 573-589, 1988.

[8] D. Hui and R. B. Jackson, "Geographical and interannual variability in biomass partitioning in grassland ecosystems: a synthesis of field data," New Phytologist, vol. 169, no. 1, pp. 85-93, 2006.

[9] A. C. Risch, M. F. Jurgensen, and D. A. Frank, "Effects of grazing and soil micro-climate on decomposition rates in a spatiotemporally heterogeneous grassland," Plant and Soil, vol. 298, no. 1-2, pp. 191-201, 2007.

[10] J. Silvertown, M. E. Dodd, K. McConway, J. Potts, and M. Crawley, "Rainfall, biomass variation, and community composition in the park grass experiment," Ecology, vol. 75, no. 8, pp. 2430-2437, 1994.

[11] M. D. Walker, P. J. Webber, E. H. Arnold, and D. Ebert-May, "Effects of interannual climate variation on aboveground phytomass in alpine vegetation," Ecology, vol. 75, no. 2, pp. 393408, 1994.

[12] P. Holub, "The expansion of Calamagrostis epigejos into alluvial meadows: comparison of aboveground biomass in relation to water regimes," Ekologia Bratislava, vol. 21, no. 1, pp. 27-37, 2002.

[13] D. Han, P. O'Kiely, and D. W. Sun, "Application of waterstress models to estimate the herbage dry matter yield of a permanent grassland pasture sward regrowth," Biosystems Engineering, vol. 84, no. 1, pp. 101-111, 2003.

[14] D. Hölscher, S. Schmitt, and K. Kupfer, "Growth and leaf traits of four broad-leaved tree species along a hillside gradient," Forstwissenschaftliches Centralblatt, vol. 121, no. 5, pp. 229239, 2002.
[15] D. C. Hayes and T. R. Seastedt, "Root dynamics of tallgrass prairie in wet and dry years," Canadian Journal of Botany, vol. 65, no. 4, pp. 787-791, 1987.

[16] L. Andrzejewska, "Root production of some grass communities on peat soil in river valleys of Biebrza and Narew," Polish Ecological Studies, vol. 17, no. 1-2, pp. 63-72, 1991.

[17] C. B. Pandey and J. S. Singh, "Rainfall and grazing effects on net primary productivity in a tropical savanna, India," Ecology, vol. 73, no. 6, pp. 2007-2021, 1992.

[18] A. A. Titlyanova, I. P. Romanova, N. P. Kosykh, and N. P. Mironycheva-Tokareva, "Pattern and process in above-ground and below-ground components of grassland ecosystems," Journal of Vegetation Science, vol. 10, no. 3, pp. 307-320, 1999.

[19] J. F. Weltzin, J. Pastor, C. Harth, S. D. Bridgham, K. Updegraff, and C. T. Chapin, "Response of bog and fen plant communities to warming and water-table manipulations," Ecology, vol. 81, no. 12, pp. 3464-3478, 2000.

[20] K. Weißhuhn, H. Auge, and D. Prati, "Geographic variation in the response to drought in nine grassland species," Basic and Applied Ecology, vol. 12, no. 1, pp. 21-28, 2011.

[21] M. R. Bakker, L. Augusto, and D. L. Achat, "Fine root distribution of trees and understory in mature stands of maritime pine (Pinus pinaster) on dry and humid sites," Plant and Soil, vol. 286, no. 1-2, pp. 37-51, 2006.

[22] L. Ibrahim, M. F. Proe, and A. D. Cameron, "Main effects of nitrogen supply and drought stress upon whole-plant carbon allocation in poplar," Canadian Journal of Forest Research, vol. 27, no. 9, pp. 1413-1419, 1997.

[23] M. M. Qaderi, L. V. Kurepin, and D. M. Reid, "Growth and physiological responses of canola (Brassica napus) to three components of global climate change: temperature, carbon dioxide and drought," Physiologia Plantarum, vol. 128, no. 4, pp. 710-721, 2006.

[24] M. E. Wedderburn, J. R. Crush, W. J. Pengelly, and J. L. Walcroft, "Root growth patterns of perennial ryegrasses under well-watered and drought conditions," New Zealand Journal of Agricultural Research, vol. 53, no. 4, pp. 377-388, 2010.

[25] M. Tesařová, "Micro-organisms in grasslands," in Structure and Functioning of Seminatural Meadows, M. Rychnovská, Ed., pp. 245-275, Academia, Prague, Czech Republic, 1993.

[26] M. van Oorschot, N. van Gaalen, E. Maltby, N. Mockler, A. Spink, and J. T. A. Verhoeven, "Experimental manipulation of water levels in two French riverine grassland soils," Acta Oecologica, vol. 21, no. 1, pp. 49-62, 2000.

[27] I. Tůma, "Release of nutrients from decomposing grass litter on deforested areas affected by air pollution in the Beskydy Mts," Ekologia Bratislava, vol. 21, no. 2, pp. 201-220, 2002.

[28] X. Yang, M. Wang, Y. Huang, and Y. Wang, "A one-compartment model to study soil carbon decomposition rate at equilibrium situation," Ecological Modelling, vol. 151, no. 1, pp. 63-73, 2002.

[29] Z. Fischer, M. Niewinna, and I. Yasulbutaeva, "Intensity of organic matter decomposition in various landscapes of Caucasus (Daghestan)," Polish Journal of Ecology, vol. 54, no. 1, pp. 105116, 2006.

[30] T. Teklay, "Decomposition and nutrient release from pruning residues of two indigenous agroforestry species during the wet and dry seasons," Nutrient Cycling in Agroecosystems, vol. 77, no. 2, pp. 115-126, 2007.

[31] M. Köchy and S. D. Wilson, "Semiarid grassland responses to short-term variation in water availability," Plant Ecology, vol. 174, no. 2, pp. 197-203, 2004. 
[32] L. Yahdjian, O. E. Sala, and A. T. Austin, "Differential controls of water input on litter decomposition and nitrogen dynamics in the Patagonian steppe," Ecosystems, vol. 9, no. 1, pp. 128 141, 2006.

[33] L. Yahdjian and O. E. Sala, "Vegetation structure constrains primary production response to water availability in the Patagonian steppe," Ecology, vol. 87, no. 4, pp. 952-962, 2006.

[34] L. Yahdjian and O. E. Sala, "A rainout shelter design for intercepting different amounts of rainfall," Oecologia, vol. 133, no. 2, pp. 95-101, 2002.

[35] R. O. Kuchenbuch, K. T. Ingram, and U. Buczko, "Effects of decreasing soil water content on seminal and lateral roots of young maize plants," Journal of Plant Nutrition and Soil Science, vol. 169, no. 6, pp. 841-848, 2006.

[36] M. Murphy, R. Laiho, and T. R. Moore, "Effects of water table drawdown on root production and aboveground biomass in a boreal bog," Ecosystems, vol. 12, no. 8, pp. 1268-1282, 2009.

[37] C. A. Perez and J. L. Frangi, "Grassland biomass dynamics along an altitudinal gradient in the Pampa," Journal of Range Management, vol. 53, no. 5, pp. 518-528, 2000.

[38] D. M. Eissenstat and R. D. Yanai, "The ecology of root lifespan," Advances in Ecological Research, vol. 27, pp. 1-60, 1997.

[39] A. H. Fitter, J. D. Graves, G. K. Self, T. K. Brown, D. S. Bogie, and K. Taylor, "Root production, turnover and respiration under two grassland types along an altitudinal gradient: influence of temperature and solar radiation," Oecologia, vol. 114, no. 1, pp. 20-30, 1998.

[40] B. Speidel, "Primary production and root activity of a Golden Oat meadow with different fertilizer treatments," Polish Ecological Studies, vol. 2, pp. 77-89, 1976.

[41] L. M. Pietola and A. J. Smucker, "Fine root dynamics of alfalfa after multiple cuttings and during a late invasion by weeds," Agronomy Journal, vol. 87, no. 6, pp. 1161-1169, 1995.

[42] I. C. Meier and C. Leuschner, "Belowground drought response of European beech: fine root biomass and carbon partitioning in 14 mature stands across a precipitation gradient," Global Change Biology, vol. 14, no. 9, pp. 2081-2095, 2008.

[43] D. A. Frank, "Drought effects on above-and belowground production of a grazed temperate grassland ecosystem," Oecologia, vol. 152, no. 1, pp. 131-139, 2007.

[44] J. Jakrlová, "Flooded meadow communities. An analysis of productivity in a dry year," Folia Geobotanica and Phytotaxonomica, vol. 6, pp. 1-27, 1971.

[45] M. Valdés, H. Asbjornsen, M. Gómez-Cárdenas, M. Juárez, and K. A. Vogt, "Drought effects on fine-root and ectomycorrhizal-root biomass in managed Pinus oaxacana Mirov stands in Oaxaca, Mexico," Mycorrhiza, vol. 16, no. 2, pp. 117-124, 2006.

[46] E. E. Bontti, J. P. Decant, S. M. Munson et al., "Litter decomposition in grasslands of Central North America (US Great Plains)," Global Change Biology, vol. 15, no. 5, pp. 1356-1363, 2009.

[47] K. Fiala, "Underground biomass in meadow stands," in Functioning of Meadow Ecosystems, M. Rychnovská, Ed., pp. 133153, Academia, Prague, Czech Republic, 1993.

[48] K. Fiala, "Underground plant biomass of grassland communities in relation to mowing intensity," Acta Scientiarum Naturalium Academiae Scientiarum Bohemicae Brno, vol. 31, no. 6, pp. 1-54, 1997. 

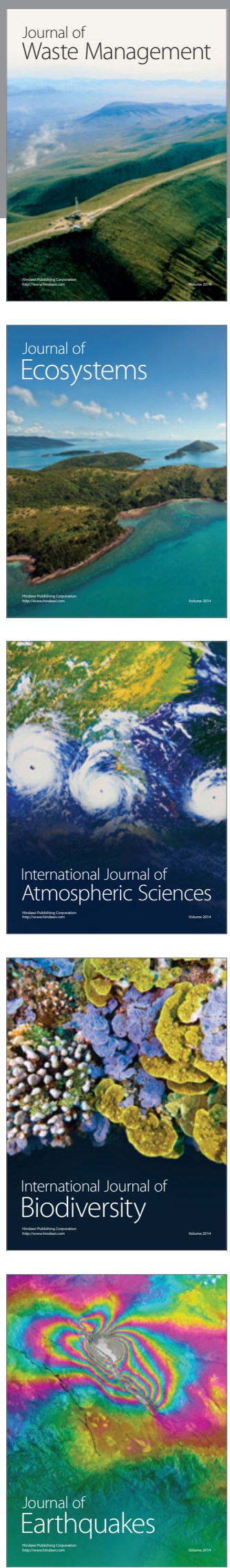
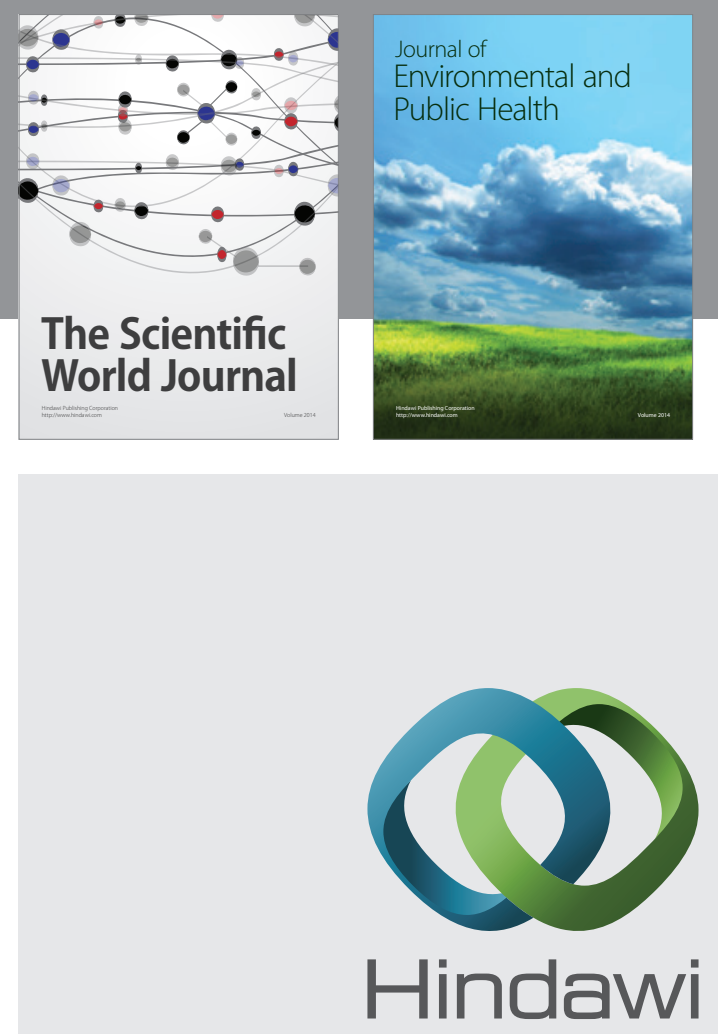

Submit your manuscripts at

http://www.hindawi.com
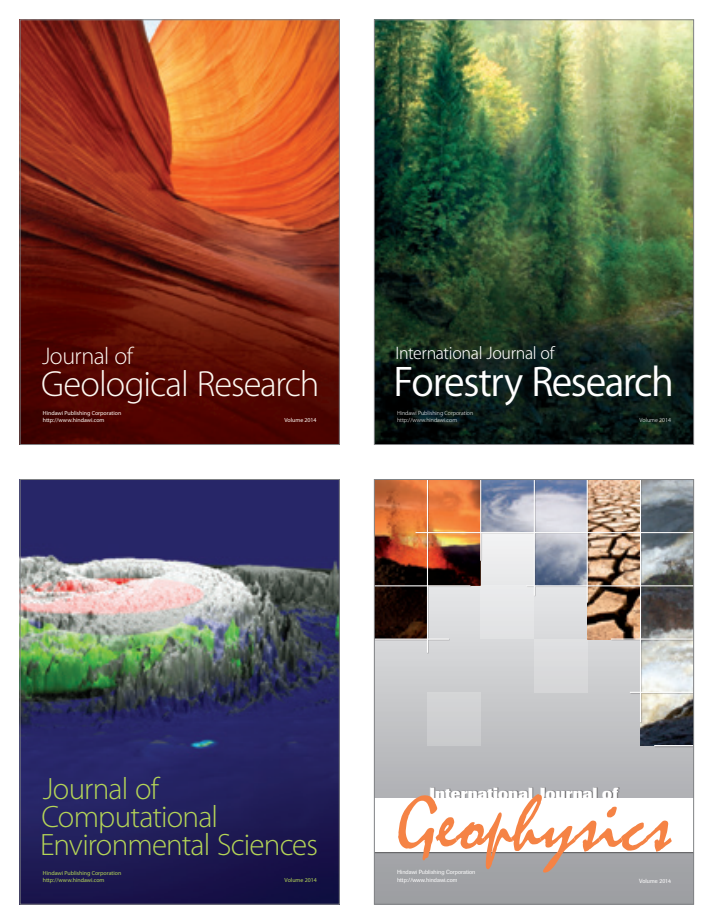
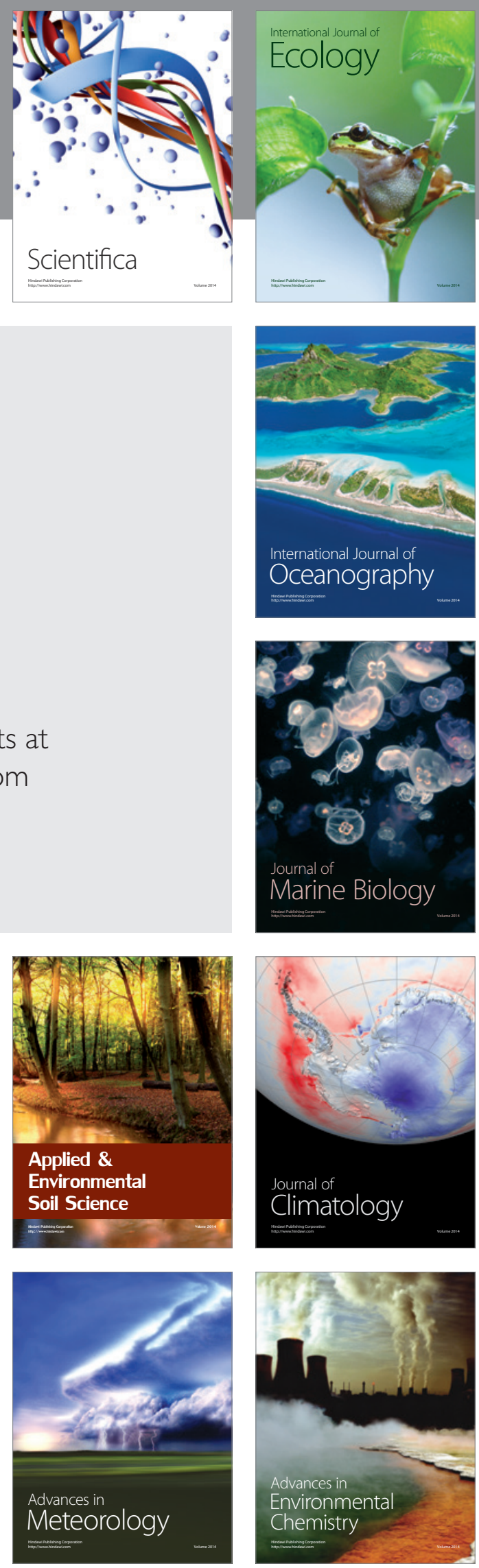